\title{
Impact of Production Practices on Organoleptic Intensity Scale of Different Rice Cultivars
}

\author{
Amit Kesarwani ${ }^{1,2, \#}$, Madhu Sharma ${ }^{3, *}$, Sachin Kumar Vaid ${ }^{4, \#}$ and Shih Shiung Chen ${ }^{5, \#}$ \\ ${ }^{1}$ Department of Agronomy, School of Agriculture, Lovely Professional University, Phagwara, Punjab 144411, \\ India \\ ${ }^{2}$ Department of Agronomy, School of Agriculture and Natural Resources, National Chung Hsing University, \\ Taichung 40227, Taiwan, R.O.C. \\ ${ }^{3}$ Department of Horticulture, School of Agriculture, Lovely Professional University, Phagwara, Punjab 144411, \\ India \\ ${ }^{4}$ Department of Microbiology, School of Agriculture, Lovely Professional University, Phagwara, Punjab \\ 144411, India \\ ${ }^{5}$ Department of Post Modern Agriculture, Ming Dao University, Changhua County 52345, Taiwan, R.O.C.
}

\begin{abstract}
The purpose of this research was to relate mean organoleptic scores of organically and conventionally grown rice $(n=5)$ in japonica cultivars (Taikeng No. 16 and Kaohsiung No. 139). The 0-7 organoleptic scale is used in trials to measure the agronomic practices impact on sensory attributes of rice cultivars. However, the precise relationship between farming system and organoleptic analysis of rice remains independent variables. Judges $(n=10)$ used a common 0-7 scale to report the 6 sensory attributes viz. appearance, aroma, flavor, cohesion, hardness and overall acceptability while keeping cultivar Taikeng No. 9 as control. The scale ranges from -3 to +3 as very poor to excellent. The study demonstrates sensory attributes as inherited trait of rice; while no improvement found in cooking and eating quality under seasonal or agronomic variations. Interestingly, the aroma was reported as only better parameter when grown under organic farming compared to conventional farming ( -0.49 and -0.62 over control, respectively). Also, the positive co-relationship exists between amylose content and organoleptic analysis while antagonistic link to crude protein content. The study cleared that management method, per se, did not influence any flavory attributes and detected no changes by the sensory panel. Further descriptive analysis needed with different conditions such as variety, degree of milling, growing location and moisture content which also played significant role in determining flavor and eating quality of rice cultivars.
\end{abstract}

Keywords: organic farming, sensory evaluation, cooked rice, eating quality.

\section{INTRODUCTION}

The rice grain qualities are measurable factors which indirectly indicated the crop growth environment and nutrient status of soil. Amylose, crude protein content and grain chalkiness are the participatory factors which in turn may influence the sensory properties of cooked rice also. The protein content of rice grains derived from translocation of accumulated plant nitrogen at flowering [1]. Hence, the rate and time of fertilizer application play crucial role in protein content of rice, nevertheless, the type of fertilizer use $[2,3]$. It was timely reported that, organically grown rice cultivars found less protein content than conventionally grown rice grains due to lower nitrogen content of organic inputs. Low protein content of cooked rice found softer and difficult to chew than high protein rice $[4,5]$. Sometimes, similar cultivar rice samples are also reported tasteful than those with high protein. However,

*Address correspondence to this author at the School of Agriculture, Lovely Professional University, Phagwara, Punjab 144411, India;

Tel: +91-843790641; E-mail: madhusharma.1982@gmail.com

\#Co-Author E-mails: getkesar@gmail.com, sachinsbaba@yahoo.com,

organic@mdu.edu.tw a decrease in amylose content has been observed concurrent with an increase in protein content with nitrogen application or uptake [6]. Amylose, a predictor of cooked rice texture, is generally directly correlated with hardness or firmness [7-14].

The perceptions of sensory quality only by individual properties can biased or misclassify the rice classification. Therefore, the proper assessment and actual judgment could be only possible by a combination of sensory, physical and eating qualities. Consumers' acceptability of rice likely remains on the choice of hardiness and stickiness [15]. However, the overall acceptance of any rice largely varies geographically based on the preferences. Abundant information available on the influence of organic or mineral fertilization on the biological and nutritional quality of rice, however, few studies has been conducted for the comparative analysis of specific rice cultivars grown locally under these agronomic practices.

Among organic treatments, farmyard manure contributed the least in terms of protein content. The 
study suggested that organic nutrient sources can perform comparatively well in terms of chemical and physico-chemical properties, and cooking quality of rice [3]. Also, higher amylose content and similar eating quality in organic Thai rice is possible despite of conventional practice [16].

Rice has an ability to utilize other $\mathrm{N}$ sources also as an advantage under competitive available $\mathrm{N}$ pool in the soil. The protein content of rice grains in organic practices increasingly develop, which attributed to the alternate availability of nitrogen supply as organic $\mathrm{N}$ that increases uptake $[17,18]$. Keeping this view, our study focused on elaboration of relationship of different agronomic farming on the sensory properties of japonica rice.

\section{MATERIALS AND METHODS}

\section{Rice Samples}

Commercial milled rice Taikeng No. 9 (TK9) and Kaoshiung No. 139 (KSH139) available locally was purchased based on the specific agronomic practice (organic or conventional farming) from year 2009 to 2011. Cultivar TK9 and KSH139 are coarse grains rice popularly grown in Central Taiwan (Chiayi County) and Eastern Hualien County (Taiwan, ROC), respectively (Appendix 2 and 3). The procured organic rice samples were collected from established Organic Farmers market in National Chung Hsing University, Taichung. However, the conventional rice collected from the nearest neighboring farmers of similar location of organic farms. Rice cultivation taken twice a year during February to June (first crop) and August to November (second crop) in Taiwan and study included both seasons crop for 2 years.

No physical or biological contaminations were noticed during procurement and samples were stored in refrigerator at 4 degree centigrade in vacuumpackaged polyethylene pouches until further analysis.

\section{General Chemical Analysis}

Moisture, protein, fat, crude fiber and ash were determined by American Association of Cereal Chemists [19] approved methods. Total carbohydrates were determined by difference.

\section{Sensory Analysis of Cooked Rice}

For analysis, rice grains of $20 \mathrm{~g}$ each sample rinsed three times thoroughly with water. Later, mixed with 42 $g$ of water (in a ratio of 1:2.1) in $100 \mathrm{cc}$ beaker and it was sealed with thin aluminum foil retaining at room temperature $\left(22 \pm 2^{\circ} \mathrm{C}\right)$ for soaking. Thirty minutes later, randomly 4 samples were kept in an automatic rice cooker (TAC-IOH Tatung Co.), followed by 10-min holding period [20]. Rest of the samples were treated same. For sensory analysis, cooked rice samples (including Taikeng No.9 used as the control) were served in a plate, and results recorded in specially designed data sheet by 10 experienced panelists who were trained in the principles and concepts of descriptive sensory analysis [20]. Degree scales of 7 points range from +3 to -3 were used to evaluate the

Table 1: F-Values of Sensory Panel Score of Rice Cultivars Influenced by Agricultural Practice in Two Crop Seasons

\begin{tabular}{|c|c|c|c|c|c|c|}
\hline Parameter & Appearance & Aroma & Flavor & Cohesion & Hardness & Overall \\
\hline Organic & $-0.72 b$ & $-0.49 a$ & $-0.59 a$ & $-0.64 a$ & $0.40 \mathrm{a}$ & $-0.66 a$ \\
\hline Conventional & $-0.58 a$ & $-0.62 b$ & $-0.55 a$ & $-0.59 a$ & $0.49 a$ & $-0.60 a$ \\
\hline \multicolumn{7}{|c|}{ F-values } \\
\hline Properties & $* * * *$ & $* * * *$ & $* * * *$ & $* * * *$ & $* * * *$ & $* * * *$ \\
\hline season (S) & ns & ns & ns & * & ns & ns \\
\hline treatment $(T)$ & $* * * *$ & $* * *$ & ns & ns & ns & ns \\
\hline cultivar (C) & $* * * *$ & $* * * *$ & $* * * *$ & $* * * *$ & $* * * *$ & $* * * *$ \\
\hline$S^{*} T$ & $* * * *$ & $* * * *$ & $* * * *$ & $* * * *$ & $* *$ & $* * * *$ \\
\hline$S^{*} C$ & $* * * *$ & $* * * *$ & $* * * *$ & $* * * *$ & $* * * *$ & $* * * *$ \\
\hline$T^{\star} C$ & ns & $* * * *$ & $* * *$ & ** & $* * * *$ & ns \\
\hline$S^{\star} T^{\star} C$ & $* * * *$ & $\star * * *$ & $\star * * *$ & $\star * * *$ & $* * * *$ & $* * * *$ \\
\hline
\end{tabular}

Values for each parameter followed by a different letter within each row are significantly different, $P \leq 0.05$ (Duncan's Multiple Range Test). Rating evaluated by sensory panelists in comparison with rice cultivar Taikeng No.9 which cultivated in chemical farming, as a Control. Where ',+ 0 and -' denote ratings higher, equal to, and lower than the control, respectively. $\mathrm{ns}=$ values statistically non-significant $(\mathrm{P}>0.05) .{ }^{*}=\mathrm{P} \leq 0.05 ;{ }^{* *}=\mathrm{P} \leq 0.01 ;{ }^{* * *}=\mathrm{P} \leq 0.001 ;{ }^{* \star *}=\mathrm{P} \leq 0.0001$. 
intensity of each sensory attributes (very poor $=-3$, excellent $=+3)($ Appendix 1$)$.

\section{RESULTS AND DISCUSSION}

It was concluded from the findings that cooking and eating quality of rice is inherited property and significantly influenced among rice cultivars (Tables 1 to 3) only. No changes reported under different agronomic practices or cultivation period (Tables 1 \& 2). However, an improvement in aroma is quite possible if rice grown under organic farming (Table $\mathbf{1}$ ).

Earlier long term study suggested better eating quality as much stickier if rice grown under organic farming. Also the pasting properties such as peak viscosity and breakdown can improve eating qualities [21]. Our research findings had contrary results, as organic rice has no changes in breakdown and cohesiveness values (data not shown) but reported lower than their conventional counterparts.

Except the grain hardness, the analysed cultivars categorized as 'poor quality' comparatively to Taikeng
No.9 (control) as average scores was found inferior (Tables 1 to 3). But, among the cultivars Kaohsiung No. $139(\mathrm{KSH}-139)$ had better eating quality than Taikeng No. 16. The grain hardiness influenced positively under TK-16 cultivar, spring crop as well as conventionally grown rice. It has been attributed by amylose, as indirect precursor of cooked rice texture, which is directly related to hardness and grain firmness [22], which was in agreement to our studies also. The pasting properties such as setback values and cooked rice hardiness have negative interaction in our study, which on contrary to earlier agreements [23, 24]. Negative interaction between two properties might be attributed to growing conditions and genotypic difference of cultivars. Significant higher protein content was reported in our further studies in conventionally grown rice than organic rice [25] which might attributed to overall hardness in conventional produce, whereas high temperature during grain filling stage cause the low moisture content of rice that increase hardness of spring crop than fall season. Lower content of amylose in organic rice and higher springiness brings the soft

Table 2: Sensory Panel Score of Rice Cultivars (Mean Values of 2 Years) in Two Different Crop Seasons

\begin{tabular}{|c|c|c|}
\hline \multirow{2}{*}{ Properties } & \multicolumn{2}{|c|}{ Seasons } \\
\cline { 2 - 3 } & Summer & $-0.55 \mathrm{a}$ \\
\hline \hline Appearance & $-0.74 \mathrm{a}$ & $-0.50 \mathrm{a}$ \\
\hline Aroma & $-0.62 \mathrm{a}$ & $-0.45 \mathrm{a}$ \\
\hline Flavour & $-0.69 \mathrm{a}$ & $-0.49 \mathrm{a}$ \\
\hline Cohesion & $-0.74 \mathrm{a}$ & $0.43 \mathrm{a}$ \\
\hline Hardness & $0.46 \mathrm{a}$ & $-0.52 \mathrm{a}$ \\
\hline Overall & $-0.75 \mathrm{a}$ & 2 \\
\hline
\end{tabular}

Rating evaluated by sensory panelists in comparison with rice cultivar Taikeng No.9 which cultivated in chemical farming, as a Control. Where ',+ 0 and -' denote ratings higher, equal to, and lower than the control, respectively. Values for each parameter followed by a different letter within each row are significantly different, $P$ $\leq 0.05$ (Duncan's Multiple Range Test).

Table 3: Sensory Panel Score of Rice Cultivars (Mean Values of 2 Years) as Affected by Treatments (Conventional or Organic)

\begin{tabular}{|c|c|c|}
\hline \multirow{2}{*}{ Properties } & \multicolumn{2}{|c|}{ Cultivars } \\
\cline { 2 - 3 } & TK-16 & $-0.31 \mathrm{a}$ \\
\hline \hline Appearance & $-0.99 \mathrm{~b}-139$ \\
\hline Aroma & $-0.93 \mathrm{~b}$ & $-0.18 \mathrm{a}$ \\
\hline Flavor & $-0.85 \mathrm{~b}$ & $-0.29 \mathrm{a}$ \\
\hline Cohesion & $-0.91 \mathrm{~b}$ & $-0.32 \mathrm{a}$ \\
\hline Hardness & $0.58 \mathrm{a}$ & $0.32 \mathrm{~b}$ \\
\hline Overall & $-0.95 \mathrm{~b}$ & $-0.31 \mathrm{a}$ \\
\hline
\end{tabular}

Rating evaluated by sensory panelists in comparison with rice cultivar Taikeng No.9 which cultivated in chemical farming, as a Control. Where '+, 0 and -' denote ratings higher, equal to, and lower than the control, respectively. Values for each parameter followed by a different letter within each row are significantly different, $P$ $\leq 0.05$ (Duncan's Multiple Range Test). 
Table 4: Correlation Coefficients between Chemical Properties of Milled Rice and Palatability after Various Fertilization Methods on the First and Second Crop in 2009-10

\begin{tabular}{|c|c|c|c|c|c|c|}
\hline \multirow{2}{*}{ Factors } & \multicolumn{9}{|c|}{ Correlation coefficient (r) } \\
\cline { 2 - 7 } & Appearance & Aroma & Flavor & Cohesion & Hardness & Overall \\
\hline \hline Spring. & $-0.09(\mathrm{~ns})$ & $0.03(\mathrm{~ns})$ & $-0.04(\mathrm{~ns})$ & $-0.10(\mathrm{~ns})$ & $-0.38^{\star *}$ & $-0.09(\mathrm{~ns})$ \\
\hline Amyl. & $0.52^{\star *}$ & $0.48^{\star * *}$ & $0.49^{* *}$ & $0.53^{\star * *}$ & $-0.30^{*}$ & $0.52^{* * *}$ \\
\hline C.P. & $-0.26^{*}$ & $-0.28^{*}$ & $-0.34^{*}$ & $-0.36^{* *}$ & $0.46^{* * *}$ & $-0.31^{*}$ \\
\hline G.C. & $-0.13(\mathrm{~ns})$ & $-0.22(\mathrm{~ns})$ & $-0.23^{*}$ & $-0.27^{*}$ & $0.11(\mathrm{~ns})$ & $-0.24^{*}$ \\
\hline
\end{tabular}

Amylose = Amyl; Crude Protein = C.P.; Gel consistency = G.C.; ns $=$ values statistically non-significant at $P \leq 0.05 .{ }^{*}=P \leq 0.05 ;{ }^{\star \star \star}=P \leq 0.0001 ;{ }^{\star \star}=P \leq 0.001$.

starch of rice compared to conventional samples. Higher content of protein tends to less swelling of starch grain by forming a gel layer surrounding the grain and let absorb less water for swelling, while comparatively enhanced the hardness. Other studies have contrary results, higher cohesiveness and hardness of conventionally grown rice with better score for eating quality compared to organic rice [26]. It was found that cultivars grown in organic have low overall acceptability as compared to conventional practice that in agreement with previous studies of rice [27], but contrast results found in our study related to seasonal and genotypic analysis.

Chemical compositions of rice grain affect the cooking quality and found high amylose cultivars are basically firmer and less sticky when cooked than lowamylose cultivars [28]. However, our study shown contrary results that higher amylose content in different parameters of study as conventional farming, second crop and $\mathrm{KSH}-139$ presented higher cohesiveness than above theory. It might be attributed to milling degree of collected samples in different practices. Higher milling degree increase the amylose content but decrease the protein content as removal of bran layer which attributed the restriction of moisture migration in rice kernels during cooking [29].

Overall acceptance of tested samples were not significantly different $(P>0.05)$ due to external factors (season and farming). This parameter may be influenced by other quality parameters, as solely changes in any eating quality parameters may not provide significant impact on the overall acceptance [24].

Experimental results revealed that the amylose content of milled rice was negatively correlated with cooked rice hardness but positively correlated with overall sensory score of palatability (Table 4). Positive correlation of amylose content with aroma and flavor was also finding in earlier studies of various rice genotypes [30]. The crude protein content of milled rice was negatively correlated with cohesiveness, aroma and overall palatability of cooked rice, but found positive correlation with hardness of cooked rice. Results are in agreements with previous studies of physicochemical properties of rice under organic farming [22, 31]. Similarly, protein content was weakly, negatively correlated with stickiness, and positively correlated with roughness of rice [32]. Also, higher $\mathrm{N}$ content of rice grain can influence the sensory characteristics and cause inverse relation with the aroma, stickiness and softness of cooked aromatic rice [33, 34]. Also, gel consistency and springiness have found negative correlation with sensory parameters which was in contrary findings to the Lee et al. [31].

In general, differences in pasting and physicochemical properties of diverse cultivars grown conventionally and organically were attributed to differences in protein content. However, it was clear from results that management method, per se, did not influence any flavory attributes and detected no changes by the sensory panel. Further descriptive analysis needed with different conditions such as variety, degree of milling, growing location and moisture content which also played significant role in determining flavor and eating quality of rice cultivars [35]. Thus, processors who purchase organic rice can be assured that there will be no negative impact on functionality but higher aroma content will be find which associated with reduced protein content, presumably due to reduced nitrogen uptake [22].

\section{ACKNOWLEDGEMENT}

We are so grateful to Dr. Madhu Sharma and Dr. Sachin Kumar Vaid for developing the article and suggestions to improve the article. Also like to thanks Professor Chen for contributing their valuable suggestions and guidance during research. 


\section{APPENDIX}

\section{Appendix 1: $\quad$ Taste Panel Test Score for Rice Grading}

\begin{tabular}{|c|c|c|c|c|c|c|c|}
\hline \multirow{2}{*}{ Item } & \multicolumn{7}{|c|}{ Scale $^{1}$} \\
\hline & +3 & +2 & +1 & 0 & -1 & -2 & -3 \\
\hline Appearance & excellent & better & good & as control & poor & poorer & Very poor \\
\hline Aroma & excellent & better & good & as control & poor & poorer & Very poor \\
\hline Flavor & excellent & better & good & as control & poor & poorer & Very poor \\
\hline Cohesion & excellent & better & good & as control & poor & poorer & Very poor \\
\hline Hardness & excellent & better & good & as control & poor & poorer & Very poor \\
\hline Overall in sensory evaluation & excellent & better & good & as control & poor & poorer & Very poor \\
\hline
\end{tabular}

${ }^{1}$ Where,+ 0 and - denote ratings higher, equal to, and lower than the control (Taikeng No. 9), respectively.

Appendix 2: Detail of Physiochemical Properties of Cultivar TK-16 Rice Collected from Farmer's Market and Field

\begin{tabular}{|c|c|c|}
\hline Properties of white rice & \multicolumn{2}{|c|}{ Taikeng No. 16 } \\
\hline Nutritional value (per $\mathbf{1 0 0} \mathrm{g})$ & Conventional & 354 \\
\hline Calories (kcal) & 355 & 4.9 \\
\hline Protein $(\mathrm{g})$ & 5.2 & 1.2 \\
\hline Fat $(\mathrm{g})$ & 1.3 & 0.4 \\
\hline a. saturated $(\mathrm{g})$ & 0.5 & 0 \\
\hline b. unsaturated $(\mathrm{g})$ & 0 & 80.9 \\
\hline Carbohydrate $(\mathrm{g})$ & 78.6 & 4 \\
\hline Sodium $(\mathrm{mg})$ & 4 & \\
\hline
\end{tabular}

\section{Appendix 3: Detail of Physiochemical Properties of Cultivar KSH-139 Rice Collected from Farmer's Market and Field}

\begin{tabular}{|c|c|c|}
\hline Properties of white rice & \multicolumn{2}{|c|}{ Kaohsiung No. 139} \\
\hline A. permissible limit & Conventional & Organic \\
\hline Shape & Short and bold & Short and bold \\
\hline Moisture (\%) & 14.5 & 14.5 \\
\hline Foreign particles (\%) & 0.2 & 0.1 \\
\hline Bran (\%) & 0 & 0 \\
\hline Brown rice $(\%)$ & 0 & 0 \\
\hline Heat damaged kernels (\%) & 0.3 & 0.1 \\
\hline Damaged kernels (\%) & 2 & 1 \\
\hline Off-type kernel (\%) & 3 & 1 \\
\hline Broken kernel (\%) & 10 & 5 \\
\hline Chalky kernel (\%) & 10 & 5 \\
\hline Non-opaque waxy kernel (\%) & - & - \\
\hline \multicolumn{3}{|l|}{ B. Nutritional value (per $100 \mathrm{~g}$ ) } \\
\hline Calories (kcal) & 356 & 349.7 \\
\hline Protein $(\mathrm{g})$ & 6.8 & 5.3 \\
\hline
\end{tabular}




\begin{tabular}{|c|c|c|}
\hline Fat $(\mathrm{g})$ & 1.3 & 0.5 \\
\hline a. saturated $(\mathrm{g})$ & 0.3 & - \\
\hline b. unsaturated $(\mathrm{g})$ & 0 & - \\
\hline Carbohydrate $(\mathrm{g})$ & 75.5 & 81.1 \\
\hline Sodium $(\mathrm{mg})$ & 4 & 12.3 \\
\hline
\end{tabular}

\section{REFERENCES}

[1] Perez CM, Cagampang GB, Esmama BV, Monserrate RU, Juliano BO. Protein metabolism in leaves and developing grains of rices differing in grain protein content. Plant Phys 1973; 51: 537-42.

http://dx.doi.org/10.1104/pp.51.3.537

[2] Shu YY. Effect of application of different types of organic composts on rice growth under laboratory conditions. Soil Sci Plant Nutr 2005; 51: 443-9. http://dx.doi.org/10.1111/j.1747-0765.2005.tb00051.x

[3] Saha S, Pandey AK, Gopinath KA, Bhattacharaya GR, Kundu S, Gupta HS. Nutritional quality of organic rice grown on organic composts. Agron Sustain Dev 2007; 27: 223-9. http://dx.doi.org/10.1051/agro:2007002

[4] Primo E, Casas A, Barber S, Barber CB. Factores decalidad del arroz. VI. Influencia de ]as proteinas sobre la calidad decoccion. Proteinas en la capa extern. Rev Agroquim Technol Alimentos 1962; 2: 135.

[5] Tamaki M, Ebata M, Tashiro T, Ishikawa M. Physicochemical studies on quality formation of rice kernel. II. Changes in quality of rice kernel during grain development. Jpn J Crop Sci 1989; 58: 659-63. http://dx.doi.org/10.1626/jcs.58.659

[6] Prakash YS, Bhadoria PBS, Amitava R, Rakshit A. Relative efficacy of organic manure in improving milling and cooking quality of rice. Int Rice Res Notes 2002; 27: 43-4.

[7] Juliano BO, Onate LU, del Mundo AM. Relation of starch composition, protein content, and gelatinization temperature to cooking and eating qualities of milled rice. Food Technol 1965; 19: 1006-11.

[8] Perez CM, Juliano BO. Indicators of eating quality for nonwaxy rices. Food Chem 1979; 4: 185-95. http://dx.doi.org/10.1016/0308-8146(79)90003-7

[9] Sowbhagya CM, Ramesh BS, Bhattacharya KR. The relationship between cooked rice texture and the physiochemical characteristics of rice. J Cereal Sci 1987; 5: 287-97. http://dx.doi.org/10.1016/S0733-5210(87)80029-2

[10] del Mundo AM, Kosco DA, Juliano BO, Siscar JJH, Perez $\mathrm{CM}$. Sensory and instrumental evaluation of texture of cooked and raw milled rices with similar starch properties. J Texture Stud 1989; 20: 97-110.

http://dx.doi.org/10.1111/j.1745-4603.1989.tb00423.x

[11] Ohtsubo K, Siscar JJH, Juliano BO, Iwasaki T, Yakoo M. Comparative study of texturometer and Instron texture measurements on cooked Japanese milled rices. Rep Nat Food Res Inst 1990; 54: 1-9.

[12] Perez CM, Juliano BO, Boume MC, Anzaldua-Morales A. Hardness of cooked milled rice by instrumental and sensory methods. J Texture Stud 1993; 24: 81-94. http://dx.doi.org/10.1111/j.1745-4603.1993.tb01279.x

[13] Kawamura S, Natsuga M, Itoh K. Near-infrared reflectance spectroscopy for rice taste evaluation. Paper No. 96-3032. 1996; ASAF: St. Jospeh, Ml.

[14] Lu X, Wu L, Pang L, et al. Effects of plastic film mulching cultivation under non-flooded condition on rice quality. J Sci Food Agric 2007; 87: 334-9. http://dx.doi.org/10.1002/jsfa.2729
[15] Juliano BO, Perez CM, Barber S, et al. Instrumental cooperative comparison of instrument methods for cooked rice texture. J Texture Stud 1981; 12: 17-38. http://dx.doi.org/10.1111/j.1745-4603.1981.tb00533.x

[16] Wangsomnuk, PP, Saenprom K, Poosittisak S, Pongdontri P, Srivvong $\mathrm{P}$, Wangsomnuk $\mathrm{P}$, Polthanee A, Kosittrakun M. 2009. Cultivar and farming practice affect yield and quality of thai rice. As J Food Ag-Ind 2009; (Sp.): S336-42.

[17] Yamagata M, Ae N. Nitrogen uptake response of crops to organic nitrogen. Soil Sci Plant Nutr 1996; 42: 389-94.

[18] Okamoto M, Okada K. Differential responses of growth and nitrogen uptake to organic nitrogen in four gramineous crops. J Exp Bot 2004; 55: 1577-85.

http://dx.doi.org/10.1093/jxb/erh167

[19] American Association of Cereal Chemists. Approved methods of the AACC. 8th Ed. The Association: St. Paul, $\mathrm{MN} ; 1983$.

[20] Meilgaard M, Civille GV, Carr BT. Sensory Evaluation Techniques. 3rd Ed. CRC Press, Boca Raton, FL; 1999. http://dx.doi.org/10.1201/9781439832271

[21] Tamaki M, Yoshimatsu K, Horino T. Relationships between the duration of organic farming culture and amylographic characteristics and mineral contents of rice. Jpn J Crop Sci 1995; 64: 677-81. http://dx.doi.org/10.1626/jcs.64.677

[22] Champagne ET, Bett-Garber KL, Grimm CC, McClung AM. Effects of organic fertility management on physicochemical properties and sensory quality of diverse rice varieties. Cereal Chem 2007; 84: 320-7. http://dx.doi.org/10.1094/CCHEM-84-4-0320

[23] Tulyathan V, Leeharatanaluk B. Changes in quality of rice (Oryza sativa L.) cv. Khao Dawk MaLi 105 during storage. J Food Biochem 2007; 3: 415-25.

http://dx.doi.org/10.1111/j.1745-4514.2007.00125.x

[24] Tananuwong K, Malila Y. Changes in physicochemical properties of organic hulled riceduring storage under different conditions. Food Chem 2011; 125: 179-85. http://dx.doi.org/10.1016/j.foodchem.2010.08.057

[25] Kesarwani A, Chen SS, Lee JF. Determination of physicochemical properties of rice under organic farming in Taiwan. Environ and Ecol 2014; 32(4A): 1445-9.

[26] Na GS, Lee SK, Kim SY. Antioxidative effects and quality characteristics of the rice cultivated by organic farming and ordinary farming. J Korean Soc Appl Biol Chem 2007; 50: 3641.

[27] Jin J, Xu DY, Cai YX, Hu SY, Ge M, Zhu QS. Effect of Nfertilizer on main quality characters of rice and RVA profile parameters. Acta Agron Sin 2004; 30: 154-8. (in Chinese with English abstract).

[28] Juliano B, Perez CM. Major factors affecting cooked milled rice hardness and cooking time. J Texture Stud 1983; 14: 235-43.

http://dx.doi.org/10.1111/j.1745-4603.1983.tb00346.x

[29] Saleh MI, Meullenet JF. The effect of moisture content at harvest and degree of milling (based on surface lipid content) on the texture properties of cooked long-grain rice. Cereal Chem 2007; 84: 119-24.

http://dx.doi.org/10.1094/CCHEM-84-2-0119 
[30] Al-Mana H, Mahmoud RM. Evaluation of imported rice in Saudi Arabia retail markets. Bull Fac Agric Univ Cairo 1991; 42: $1225-48$

[31] Lee JF, Chen YW, Chen SS, Tsai YF. Effects of application amounts of various organic fertilizers on rice quality. TDAIS 2002; 74: 65-77.

[32] Champagne ET, Bett KL, Vinyard BI, et al. 1999. Correlation between cooked rice texture and rapid visco analyser measurements. Cereal Chem 1999; 76: 764-71. http://dx.doi.org/10.1094/CCHEM.1999.76.5.764
[33] Suwanarit A, Kreetapirom S, Buranakarn S, et al. Effect of nitrogen fertilizer on grain qualities of Khaw Dauk Mali-105 aromatic rice. Kasetsart J Nat Sci 1996; 30: 458-74.

[34] Srivastava PC, Singh US. Effect of graded levels of nitrogen and sulfur and their interaction on yields and quality of aromatic rice. J Plant Nutr 2007; 30: 811-28. http://dx.doi.org/10.1080/01904160701290113

[35] Champagne ET, Bett KL, Vinyard BT, et al. Effect of drying conditions, final moisture content and degree of milling on rice flavor. Cereal Chem 1997; 74: 566-70. http://dx.doi.org/10.1094/CCHEM.1997.74.5.566 